\title{
BeleidsonderzoekOnline
}

DOI: $10.5553 / B O / 221335502021000002001$

\author{
Bespreking van: R. Stockmann, W. Meyer \& L. Taube \\ (Eds.), The institutionalisation of evaluation in Europe, \\ Basingstoke: Palgrave Macmillan 2020
}

\section{Ben Hoetjes}

\author{
Aanbevolen citeerwijze bij dit artikel \\ Ben Hoetjes, 'Bespreking van: R. Stockmann, W. Meyer \& L. Taube (Eds.), The \\ institutionalisation of evaluation in Europe, Basingstoke: Palgrave Macmillan \\ 2020', Beleidsonderzoek Online januari 2021, DOI: \\ $10.5553 / \mathrm{BO} / 221335502021000002001$
}

In de tweede helft van de twintigste eeuw deden nieuwe ideeën over overheidsbeleid overal ter wereld hun intrede, in het kielzog van de grote internationale wederopbouwprogramma's. PPBS en later New Public Management, met beleidsevaluatie als belangrijk leerstuk, maakten van de bestuurskunde een nieuw en modern vakgebied. Internationale organisaties, de Wereldbank en de EU, vaak met een sterk Amerikaanse inslag, ondersteunden dit nieuwe denken met grootschalige financiering. De auteurs/redacteuren van dit boek bevinden zich in dit nieuwe denken, en hebben honderden beleidsevaluaties uitgevoerd in ontwikkelingslanden. Nu maken zij zich op voor een wereldwijd project, namelijk een overzicht van de beleidsevaluatie wereldwijd, en omdat zij Europeaan zijn, verbonden aan de universiteit van Saarland, op de grens van Duitsland en Frankrijk, beginnen zij met een boek over Europa. Zij beperken zich niet tot het verzamelen en redigeren van bijdragen van landenexperts over afzonderlijke landen, maar voegen daar een eigen analysehoofdstuk en een synthese aan toe, naast een stevig hoofdstuk over Duitsland.

Leidende vraag is steeds, hoe de evaluatie van overheidsbeleid is geworteld in regelgeving, politiek en samenleving. In het eerste hoofdstuk leggen de redacteuren aan de landen-auteurs drie vragen voor: hoe is de evaluatie van overheidsbeleid ingebed in het politiekbestuurlijk systeem (regelgeving, betrokkenheid van de volksvertegenwoordiging), hoe staat de samenleving (ngo's, belangengroepen, publieke opinie) tegenover beleidsevaluatie, en in hoeverre is de beleidsevaluatie geprofessionaliseerd via opleiding en de vorming van een eigen beroepsgroep? Aan de hand van deze vragen komen achtereenvolgens aan de orde een aantal landen in Noord-Europa (Denemarken en Finland), West-Europa (Nederland, België, Frankrijk, 
Duitsland, Zwitserland, Ierland en Groot-Brittannië), Zuid-Europa (Italië, Spanje en Portugal), Midden- en Oost-Europa (Tsjechië, Letland, Polen en Roemenië), en twee internationale organisaties (EU en Raad van Europa). In het afsluitende hoofdstuk geven de redacteuren hun (voorlopige) conclusies.

Beleidsevaluatie is soms in het politiek-bestuurlijke systeem verankerd door overkoepelende nationale wetgeving (de Franse en Zwitserse grondwet, de Nederlandse Comptabiliteitswet), maar meestal via lagere wetgeving of lokale/regionale regelgeving. De belangstelling en betrokkenheid van de volksvertegenwoordiging zijn zeer wisselend: in Zwitserland, Nederland en Duitsland zijn deze vrij hoog, maar elders veel geringer. Het initiatief voor evaluaties ligt meestal bij de beleid-makende en -uitvoerende overheid, maar soms ook bij het hoogste audit-orgaan (Rekenkamer) ten behoeve van het parlement.

De beleidsterreinen waarop wordt geëvalueerd, zijn in een enkel geval, bijvoorbeeld Nederland, zeer talrijk (daar worden ze 'allemaal' geëvalueerd, volgens de auteur van het Nederland-hoofdstuk), maar elders springen vooral onderwijs, ontwikkelingssamenwerking, innovatie en wetenschap, en gezondheidszorg eruit. Nederland is een echt evaluatieland.

De belangstelling vanuit de samenleving (ngo, media) voor beleidsevaluaties is in Europa in het algemeen laag, en de ontwikkeling van beleidsevaluatie als beroepsgroep (opleiding, professionalisering) is vrijwel overal zwak. Kortom, beleidsevaluatie wordt in veel landen druk beoefend, maar is nog jong en niet stevig gevestigd in de samenleving. Met talrijke schema's, indelingen en statistische analyses worden deze conclusies geadstrueerd en wetenschappelijk onderbouwd. Dit solide wetenschappelijke boek (talrijke bron- en literatuurverwijzingen per hoofdstuk, tabellen, figuren, helaas geen register) roept niettemin enige opmerkingen op.

Allereerst de ontbrekende gevallen. Afwezig zijn: IJsland (niet erg?), Noorwegen (jammer), Zweden (erg jammer, gegeven de sterke eigen verantwoordingscultuur, de ombudsman), Luxemburg (te klein?), Oostenrijk (jammer), Slowakije, Hongarije, de Balkanlanden en Griekenland (toch wel jammer, gezien de moeilijkheden van de afgelopen jaren). In het verlengde hiervan is het hoofdstuk over de EU, dat zich beperkt tot de formele regelgeving en vrijwel niets meldt over de praktijk en de doorwerking van evaluatie vanuit 'Brussel', buitengewoon mager. Dat is erg jammer, vooral omdat in veel landen van Europa, niet alleen in zuid en oost, de beleidsevaluatie is opgekomen als direct gevolg van EUbeleid. Een casestudy over bijvoorbeeld het structuurbeleid zou zeer gewenst zijn, ook al past dat op het eerste gezicht niet in een meta-studie als deze. De toevoeging, in het internationale hoofdstuk, van de Raad van Europa, kan dit gemis niet goedmaken.

Een andere opmerking betreft het gebrek aan historische diepgang, eigenlijk in het hele boek. Wie een goed beeld wil krijgen van het beeld en zelfbeeld van de overheid, van haar plaats in de samenleving 
(vertrouwen, wantrouwen, status), moet dieper gaan dan de tweede helft van de twintigste eeuw. Alleen dan kan men de voedingsbodem voor de beleidsevaluatie goed begrijpen. Het van buitenaf invliegen van beleidsevaluatoren voor een meestal korte missie, zoals de redacteuren zelf veelvuldig hebben gedaan, is zonder bekendheid van en begrip voor de nationale geschiedenis gedoemd een activiteit te blijven die onvoldoende of niet wordt benut.

Dat brengt ons tot een volgende opmerking, namelijk de ambitie van de redacteuren om met dit project de hele wereld in kaart te brengen. Dit Europese boek is het eerste in een reeks van vier, die samen een wereldatlas van beleidsevaluatiesystemen moet opleveren. Naar de mening van deze recensent is dit een over-ambitieuze opzet, waaraan men zich gemakkelijk kan vertillen.

Niettemin: als meta-studie over systemen van beleidsevaluatie is dit een leerzaam boek, dat nuttige vergelijkende vragen oproept en stof tot nadenken geeft, en tot verder onderzoek aanzet. Waarom wordt beleidsevaluatie door ambtenaren vaak beschouwd als een teken van wantrouwen, en daarom vermeden? Waarom komt de beoordeling van beleid pas onder de publieke aandacht, wanneer de partijpolitiek en de media de evaluaties zien als bruikbare grondstof voor de politieke strijd? Waarom worden veel evaluaties uitbesteed aan buitenstaanders, zoals grote internationale accountantskantoren of organisatieadviesbureaus (PricewaterhouseCoopers, Ernst \& Young, Berenschot)? Komt dat omdat men de evaluaties uitsluitend ziet in financiële termen, of omdat overheden de handen vrij willen houden? Waarom is het leereffect van evaluaties vaak onduidelijk of gering? Waarom wordt evaluatie meestal vaag omschreven, als een verlengstuk van audit, inspectie en rapportage?

Kortom: vele vragen, en een waardevol boek voor de wereldwijde kring van evaluatoren. Geen soepele lectuur, maar wel nuttig en leerzaam. 